\title{
Dynamics of Position of Public Relations of Company Media PT. Lativi Media Karya (Tv One) in Dealing with Hoax Information
}

\author{
Nikmatus Sholikah ${ }^{1}$, Maulina Pia Wulandari ${ }^{2}$, Anang Sujoko ${ }^{3}$ \\ ${ }^{1,2,3}$ Study Program of Communication Science, Faculty of Social Science and \\ Political Sciences, Brawijaya University, Malang, Indonesia \\ Email: nicmah21@gmail.com
}

\begin{abstract}
Hoaxes or false information are now increasingly easy to find in various social media and public information media, this is a challenge for the mass media industry. Hoax information connected globally via the internet can harm various fields of the company, including mass media companies or the press. The purpose of this research is to find out how the dynamics of Public Relations (PR) media company PT Lativi Media Karya or tvOne in overcoming hoax information that is detrimental to the company and what contingent factors affect the attitude of PR tvOne to solve the hoax problem. The object of research used three cases of hoax information which were quite viral in 2016, 2018 and 2020. The Contingency of Accomodation theory is the main theory used to find out the dynamics of the PR position. The research methodology used is a qualitative approach, data collection using two methods, namely semi-structured interviews and documentation, data analysis techniques using constant comparability. The result is that PR tvOne tends to lead to an advocacy positions in overcoming hoax information, even though in the case of hoax information in 2018, it is accommodation in advocacy by withdrawing demands from the police, but PR tvOne still fully defends the company or its advocacy attitude. Then, on the contingent factors in the predisposing and situational variables, each of which has six contigens, it turns out that all of the contaminants affect the PR attitude of tvOne. Researchers found two new important content for media company tvOne, namely "image" and "credibility".
\end{abstract}

Keywords: Contigency of Accomodation Theory, Mass Media, Hoax.

\section{A. INTRODUCTION}

The incessant hoax information or fake news that causes misinformation and disinformation then ends up with misleading information is a phenomenon that cannot be avoided in the midst of today's digital media development. According to the Indonesian Ministry of Communication and Informatics (Kominfo), people are easily provoked by unclear news. It was recorded that the production of hoax information was based on Ais data, a machine that scavenged negative internet content from Kominfo was found 3,801 hoaxes throughout 2019 (Pusparisa, 2019).

The current condition of hoax information can also harm all types of companies, including mass media companies or the press. Hoax information can damage the credibility of the press in the eyes of the public and result in the company's reputation being threatened. In the four pillars of the Indonesian democracy, namely the legislature, executive, judiciary and the press, the position of the press is quite important, namely as a watchdog. The press is also a means of social control in the life of the state to oversee the running of the government which 
has been running on the basis of the state mandate. Because of this, the credibility of mass media companies must be maintained in order to be trusted by the public. According to Kiousis (Wahab \& Rahmi, 2013), in modern times, press freedom and media credibility are closely related to public trust in the media. The failure of the media to maintain credibility will affect the ability of the media to carry out their normative functions.

Furthermore, when talking about news that has been in the spotlight of the mass media in the world since the end of 2019, namely the COVID-19 outbreak which has affected millions of lives, triggering a lot of hoax information in the community. In Indonesia, since the corona virus entered Indonesia on March 2, 2020, there have been thousands of hoax information popping up. Hoax information is widely spread on social media networks related to COVID-19 ranging from local, national to international issues. Minister of Communication and Informatics (Menkominfo) Johny G. Plate said that until 5 May 2020 the results of monitoring by the AIS Team of the Directorate General of Aptika, there were 1,401 hoax and disinformation content circulating in the community regarding Coronavirus Disease (Yusuf, 2020). The case of the emergence of the corona virus has become a big magnet for almost all Indonesian people, including the national news television, tvOne, which also discussed COVID-19.

In the last five years, namely 2016 to 2020, tvOne has been targeted several times for hoax content that has harmed tvOne. At least there have been several cases of hoax information or fake news that have become a separate concern by tvOne which threatens tvOne's credibility and image. One of the most recent is one of the ILC shows which is one of tvOne's flagship programs on March 3, 2020 entitled "When Corona Has Arrived in Indonesia" was accused of presenting fake sources by one of the online news portals.

Then regarding the hoax information issue, in 2016 tvOne was also attacked by hoax content through 'memes' on social media featuring TVOne's breaking news broadcast about announcing the results of the Itsbat trial to determine Eid al-Fitr 2016. The circulating image reads 1 Shawwal on Wednesday, July 6 2019, not 2016 so tvOne became the material of blasphemy on social media (Rimawan, 2016). TvOne also experienced hoax information attacks in 2018, the @bola_gila Instagram account featured tvOne's "Kabar Arena Pagi" program which showed running text of Argentina's victory over France by changing the correct score information to false, namely a score of 3-4 to 4-3 between Argentina and France. This made tvOne the target of blasphemy by nitizens on social media (Briantika, 2018).

According to Andreas Pyrcek, Head of the Global Forensic Sector for Telecommunications, Media and Entertainment, Germany, which is an Ernst \& Young Professional Services Firm, in the field of consulting, insurance, tax and law, the third largest in the world writes about media companies and hoaxes from his observations. . In an article entitled "How media organizations can get real and confront fake news", he explained, the problem of hoax information will not disappear in the future, as the world of news and finance will continue to develop 
and grow as more people get news platforms. If audiences no longer trust media channel brands as reliable sources of accurate information, brand revenue and sustainability can suffer. For example, "Advertisers may not want to be associated with a platform that hosts problematic content, this leads to ad dollars", said Emmanuel Vignal, EY Asia-Pacific Leader, Forensic Services \& Integrity (Pyrcek, 2020).

When a company experiences a hoax information attack, PR becomes one of the divisions responsible for identifying problems, arranging strategies and overseeing the resolution process. Then if we talk about PR strategies in dealing with various hoax information that occurs in media companies, then we will discuss the PR position more towards advocacy or accommodation in an effort to overcome hoaxes that threaten companies. In a journal written by Yan Jin, Augustine Pang and Glen T. Cameron entitled Strategic Communication in Crisis Govermance: Analysis of the Singapore Management of the SARS explains, the theory of Contingency of Accommodation (CA) is a theory that makes it possible to understand the dynamic nature of crises and make judgments about what attitudes are appropriate at each point in time (Jin, Pang \& Cameron, 2006).

Shin et.al (2003b) suggest that the type of attitude an organization adopts towards its publics can depend on the type of organization involved. They found that non-profit organizations are more likely to be accommodating to their publics than profit organizations (Jin, Pang \& Cameron, 2006). However, until now, researchers have not found any research that discusses how media companies handle hoax information that threatens public trust and media credibility. Then with the dynamics of the PR position based on the theory of Contingency of Accomodation is still little used, because generally PR practitioners use theory excellence. Then the researcher made a problem formulation like the following:

1. How does the dynamic position of PR media company PT Lativi Media Karya (tvOne) lead to advocacy or accommodation in dealing with hoax information?

2. What contingent factors seem to influence the position of PR in the strategy of dealing with hoax information problems that are detrimental to tvOne?

\section{B. LITERATURE REVIEW}

\section{The Effect of Hoax on Media Credibility}

Hoaxes have a cognitively shorter 'lifespan' than mass social media constructs, but the dangers of hoaxes have a very strong and widespread sporadic destructive force in society. According to Bungin, hoaxes are a serious problem in communication ethics because they can damage the image of the opponent. All hoax information is not only detrimental to the subject of hoaxes, but also attacks and destroys the ethical order in society to become a killing machine for one's character (Bungin, 2017). Various studies have been carried out in an effort to ward off and anticipate the massive spread of hoax information. 
According to The Guardian, the definition of fake news is fiction deliberately created and presented as non-fiction with the intention of misleading the recipient so that they can treat fiction as fact or become questionable fact (Alemanno, 2018). The presence of the internet has further increased the circulation of hoaxes in the world. Just like memes, their existence is very easy to spread through social media. Usually hoax content has issues that are being discussed in the community and it is very easy to lure people to share them (Aditiawarman, et al, 2019).

According to Kiousis (Wahab \& Rahmi, 2013), in modern times, press freedom and media credibility are closely related to public trust in the media. With so much hoax information, the media must be able to maintain its credibility so that it can be trusted by the public. The failure of the media to maintain credibility will affect the ability of the media to carry out their normative functions. Then, actually the media has a strong influence on the formation of thought patterns, attitudes and behavior of the public (Akil, 2012).

In basic terms, several implementing rules can be used to identify hoaxes, as described by Hartley (2012).

a. First, hoax information usually has features such as dangling words, including the sentence "Share this to anyone you know, otherwise something unpleasant will happen."

b. Second, hoax information usually does not include the date of the topic discussed, events or information that is justified, using statements such as "yesterday" or "carried by" that are missing in the explanation.

c. Third, hoax information usually does not include a deadline for the news, even though the inclusion of that date does not mean anything.

d. Fourth, there is no group that can be asked to account for the results of their citation of information, or an organization that can be identified to explain this. Anyone can say "I heard it from someone who works at Microsoft" (or some other type of company).

\section{Theory of Contingency of Accomodation (CA) in Public Relations}

Contingency of Accomodation Theory in Public Relations theory is actually a complement to the theory of excellence. This CA theory generally explains that the relationship between organizations and the public cannot really achieve a two-way symmetric position as offered in the theory of excellence. Public relations practice moves in a continuum between advocacy for organizations or clients and total accommodation for the public (Kriyantono, 2014). The win-win solution offered by the two-way symmetric model is not always an ideal offer for organizations. This is because, there are several factors that make the symmetric model difficult to apply in practice, for example several things related to legal rules, so that it does not allow a public relations officer to inform the public about this (Kriyantono, 2014).

In theory $\mathrm{CA}$ is a continuum between total accommodation and total advocacy. Accommodation can be interpreted as an adjustment to the environment, including the ability to collaborate with other parties. Advocacy can be interpreted 
as an effort to provide support and defense of organizational policies, so a PR is like a legal adviser to defend his client. It is said to be contingency because between being accommodation and advocating, a PR is influenced by possible factors so that it is situational. A PR must balance between accommodation and advocacy, because if PR is more focused on advocacy, it can be said that a PR has carried out the process of manipulating the public (Kriyantono, 2014).

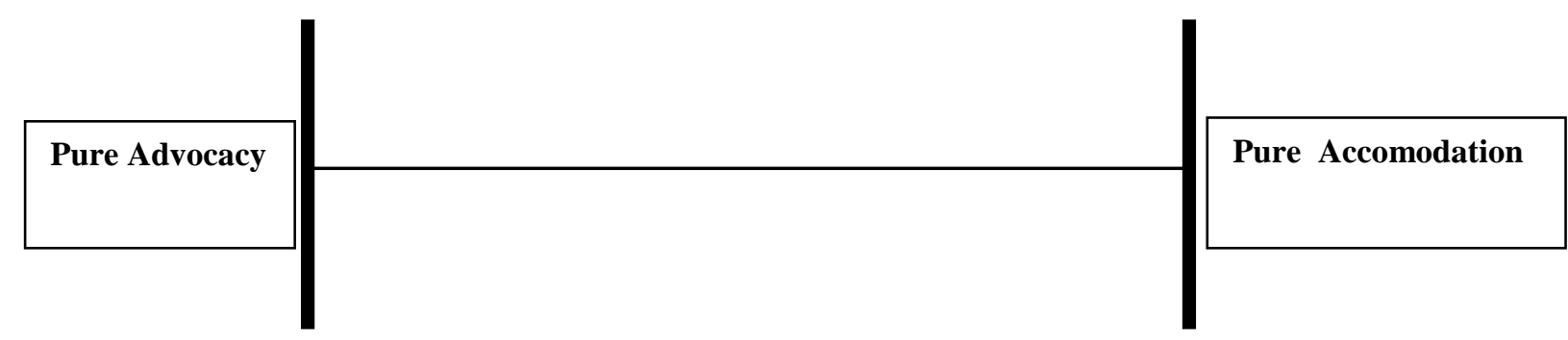

Figure 1: Advocacy and Accomodation Continuum

Source: Cancel et al 1999: 173 (Kriyantono, 2014)

The contingency of accommodation in public relations (CA) theory developed as a critique of the two-way symmetric model in the theory of excellence in public relations. According to the initiators Cameron, et al., The CA theory is a modification and complement to the normative theory (theory of excellence). CA is considered to be a more realistic portrait of a PR strategy or PR model. Public relations practice moves on a continuum between total (pure) advocacy for the organization or client and total (pure) accommodation for its public. This CA theory emphasizes that the attitude or position of a PR is very dynamic and depends on changes in the situation that occur. Changes in this situation are determined by the internal and external variables that affect the organization. Several things are included in external variables and internal variables. There are 86 variables according to Cancel, et al. (1999) which represent possibilities that can affect the nature of accommodation in the public (27 external variables in 5 sub-categories and 59 internal variables in seven sub-categories) (Kriyantono, 2014).

\section{Development of the Theory of Contingency of Accomodation (CA)}

Then in its development Cancel, et al. (1999) developed the CA theory by introducing what determines the possibility of being accommodative or advocating among practitioners. This new variable is a simplification or parsimony principle of internal and external variables that were previously raised. These two new variables, namely predisposing variables, can be interpreted as attitude tendencies and situational variables (Kriyantono, 2014).

According to Cancel, et al. (1999); Raber \& Cameron (2003), is a variable that has a major influence on the organization by helping to form a tendency to behave and establish relationships with the external public and there are variables that affect the position of the organization on the continuum during interactions with the 
public. Predisposing variables include: 1) Organizational Size, 2) Organizational Culture, 3) Business Exposure or Exposure, 4) Affiliation or access to PR with dominant groups, 5) Decision Strength and Direction of Dominant Qualifications, 6) Individual characteristics of key individuals, such as CEO (Cancel et all, 1999).

Situational variables play a role in changing attitudes and organizational stance in dealing with the public as a result of a condition or situation (Kriyantono, 2014). Situational variables include: 1) Threats such as negative news published in the media, government intervention, legal issues (litigation). 2) Potential Costs or Benefits of a Strategy (Accommodation or Advocacy). 3) Balance of interests between various publics. 4) Public perception of the issue, 5) Reputation of the organization and 6) Characteristics of the external public and its demands (Cancel, Mitrook \& Cameron, 1999).

Regarding several actions in the accommodation contingency theory described by Cance et al (1997), there are several things that must be considered, namely (Cancel, Cameron, Sallot \& Mitrook, 1997):

a. Organizations will tend to view advocacy as not only the best for itself, but also the best for the world in the long run.

b. It is impossible for the organization to practice PR in a symmetrical manner until the public has obtained powers that are almost the same as the position of the organization. Through game theory logic it follows that organizations can reap the greatest benefits by practicing asymmetric forms of communication in situations where the organization has more power than its public.

\section{METHOD}

In this study, researchers used a constructivist paradigm. In the constructivist paradigm, individuals always try to understand the world in which they live and work. They develop subjective meanings for their experiences, meanings are directed at certain objects or objects (Creswell, 2019).

This study uses a qualitative research approach that aims to explain the phenomenon in depth. This study does not prioritize population size or sampling, in fact both of them can be limited. If the data collected is deep enough and can explain the phenomenon under study, then there is no need to look for other sampling (Kriyantono, 2014). The qualitative research approach is usually referred to as the natural setting method because qualitative researchers tend to collect data where participants experience the issues they observe (Creswell, 2019).

To obtain various data and information needed, the researcher collected data using two methods, namely semi-structured interviews and documentation. This is useful for obtaining relevant data and is directly related to the problem under study. The selection of informants in this study were several TVOne PRs and several tvOne divisions that were related to overcoming hoax information that was detrimental to tvOne. The selection of informants in this study used the snowball technique. The object of this research is the hoax information observed is news that appears in 2016 
to 2020 which is the concern of PR tvOne to be immediately resolved so as not to shake tvOne's image and reputation.

This research will be conducted at the office of PT Lativi Media Karya (tvOne), Jl. Rawa Terate II No. 2, Pulo Gadung Industrial Estate, Pulo Gadung, East Jakarta Postal Code 13260. The time of the study was 1-4 March 2021 with the object of research were three hoax information issues in 2016-2020 which harm the company. In this study, researchers used constant comparative analysis techniques introduced by Classer \& Strauss, Lincoln \& Cuba (Kriyantono, 2014). The interview data analysis was carried out by one researcher following a constant comparative method for the analysis of the inductive data from the interview data. Before formal data analysis began, the researcher listened to and transcribed all recorded interviews to make them more familiar with the data and to transcribe the interview verbatim (Lincoln \& Guba, 1985).

Barney G. Galaser and Anselm L. Strouss suggested several stages of analysis using the Constant Comparative Technique, namely the stage of comparing events that can be applied to each category, the stage of combining categories and their characteristics, the stage of limiting the scope of theory and the stage of writing theory (Bungin, 2010).

Table 1: Cases to be discussed in the study

\begin{tabular}{|l|l|l|}
\hline No. & \multicolumn{1}{|c|}{ Year } & \multicolumn{1}{c|}{ Case Description } \\
\hline 1. & July 2016, & \multicolumn{1}{|c|}{$\begin{array}{l}\text { In 2016 tvOne was also attacked by hoax content } \\
\text { through 'memes' on social media featuring tvOne's } \\
\text { breaking news broadcast about the announcement of } \\
\text { the results of the Itsbat trial with the wrong date, } \\
\text { namely Eid al-Fitr 2016 to Eid al-Fitr 2019. }\end{array}$} \\
\hline 2. & 2018 Case & $\begin{array}{l}\text { In 2018, the @bola_gila account featured tvOne's } \\
\text { "Kabar Arena Pagi" program which showed a } \\
\text { running text of Argentina's victory over France by } \\
\text { changing the correct score information to false, } \\
\text { namely a score of 3-4 to 4-3 between Argentina and } \\
\text { France. }\end{array}$ \\
\hline 3. & $\begin{array}{l}\text { March 2020, March 3, 2020, entitled 'When Corona Has } \\
\text { Case }\end{array}$ & $\begin{array}{l}\text { Arrived in Indonesia', the Indonesia Laywers Club } \\
\text { (ILC) program was accused of presenting fake } \\
\text { sources by one of the online news portals } \\
\text { SintesaNews.com. }\end{array}$ \\
\hline
\end{tabular}

Source: Various Data Collaborated by Researchers

In this study, the authors conducted several techniques for the validity of research data, namely "Source Triangulation", different information data by examining the evidence from these sources and using them to build a coherent justification for themes. Then "Research Subject Competence" and "Intersubjectivity 
Agreement" or overall views, opinions or data from a subject are dialogued with opinions, views or data from other subjects (Kriyantono, 2014).

\section{RESULTS AND DISCUSSION}

Interviews were conducted on 1-4 March 2021 at different locations. Three resource persons were interviewed directly at the PT Lativi Media Karya (tvOne) office. Then two other people were interviewed via the Google Meet application. Here are the data:

Table 2. Identity of Research Informants

\begin{tabular}{|c|l|c|c|}
\hline No & \multicolumn{1}{|c|}{ Position } & Time & Location \\
\hline 1. & $\begin{array}{l}\text { TVOne PR staff in the field of } \\
\text { Government Relations }\end{array}$ & March 1, 2021 & $\begin{array}{c}\text { Bekasi, via Google } \\
\text { Meet. }\end{array}$ \\
\hline 2. & Manager PR tvOne. & March 2, 2021 & tvOne office \\
\hline 3. & General Manager (GM) Current Affairs. & March 2, 2021 & tvOne office \\
\hline 4. & GM News Gathering \& Daily. & March 3, 2021 & tvOne office \\
\hline 5. & $\begin{array}{l}\text { GM Business Devt \& Corporate } \\
\text { Communication. }\end{array}$ & March 4, 2021 & $\begin{array}{c}\text { Bekasi, via Google } \\
\text { Meet. }\end{array}$ \\
\hline
\end{tabular}

Source: Researcher

\section{Domination of Advocacy Position in Position Dynamics}

To find out the attitudes of a company's Public Relations practitioner, researchers used the Contingency of Accomodation theory or CA. CA theory argues that accommodating the public is sometimes the most ethical and best for an organization and sometimes it is very ethical and best for organizations to stand firm and fully support the organization (Strasburg, 2016). In this study, there are three cases of hoax information that are detrimental to tvOne and can show the attitude of PR tvOne in an effort to overcome these problems whether PR chooses to act towards the advocacy or accommodation continuum.

\section{First Case: Choosing an Advocacy Stance}

The effort to defend the company was realized by PR by providing clarification through tvOne's official Instagram account, namely @tvOneNews on July 5, 2016. According to the second informant, information related to writing errors for Eid al-Fitro 2016 to 2019 at the Isbat breaking news tvOne trial was proven to be untrue. His party has reviewed the broadcast, so that it has made efforts to defend it and firmly rejects the hoax information. However, it did not reach the police because trent comments and responses from netizens decreased after they clarified on social media and issued press releases in online news media.

\section{Second Case: Accommodation Attitude in Advocacy}

The initial attitude taken by PR tvOne was to be full of advocacy, namely standing in the position of defending the tvOne company. The @gila_bola account uploaded June 30, 2018 regarding hoax information on the wrong score, tvOne refused by providing clarification in a broadcast on the tvOne afternoon news on 
June 1, 2018 and uploading it on Youtube tvOne. The advocacy act did not stop there, according to the second informant, according to the management's direction, his party brought it to the realm of cyber police.

Then the researchers also took documentation data from the Tirto.id news on Monday, July 22018 with the title "tvOne Report @bola_gila Account Problem Case of Hoax World Cup Results". In the news, the PR tvOne manager went to the Integrated Police Service Center Building (SPKT) Polda Metro Jaya, Jakarta. The proof of this case report is listed as TBL / 3427 / VII / 2018 / PMJ / Dit.Reskrimsus, with Martha Uly Roha Manulang as tvOne's attorney reporting the case of hoax information @bola_gila to the police (Briantika, 2018).

On the other hand, as this case progressed according to the informant, after a while, the Instagram media account @gila_bola came to tvOne and apologized to the tvOne Arena Kabar team. TvOne finally provided an opportunity for mediation because they had good intentions and admitted their mistakes. Then According to the fifth informant, GM Business Devt \& Corporate Communication in charge of the PR division said that his party withdrew the lawsuit against the @gila_bola account because the impact was over. The @gila_bola party has apologized and posted it, they have also done good intentions by coming for mediation.

Researchers also obtained documentation data from Detik.com with the title "Hoax Case of World Cup Score, tvOne-IG Bola Gila Berdamai Account" on Thursday, February 14, 2019. Even though tvOne seems to have accommodated @gila_bola's wish to make peace, it is still on the ground. advocacy attitude, namely fully supporting the company and blaming the perpetrators who spread the hoax information. According to the second informant, the PR manager of his party does not want to underestimate hoaxes, especially hoax information which is viral and has become the center of public attention and emphasizes the deterrent effect of hoax spreading actors. From this action, PR tvOne's attitude still includes accommodation in its advocacy.

\section{Third Case: Choosing a Total Advocacy Stance}

From the documentation data obtained by researchers through the Viva.co.id news portal on Wednesday, March 4, 2020 entitled "tvOne: ILC is Impossible to Use Fake Sources", tvOne, through tvOne's Public Relations Manager, conveyed that the selection of sources for news broadcasts, tvOne will always uphold the journalistic code of ethics so that the sources are not fake like the information circulating from the Sintesa News media (Priliawito, 2020).

Then from the results of interviews with researchers, the second informant explained that tvOne is the number one news tv in Indonesia and ILC is the favorite program of choice of viewers so that his party immediately took action to defend himself. PR tvOne together with tvOne's attorneys and staff have officially reported to Polda Metro Jaya a few days after the hoax information emerged. Until now, in 2021, the process is still ongoing and his party also does not want mediation.

Furthermore, the fifth informant, GM Business Devt \& Corporate Communication, also responded that Sintesa News had violated the law. They did 
not cover both sides, there was no confirmation from tvOne in the news. They also don't admit that they're guilty. So it is very clear that the Sintesa News media is spreading hoaxes that are prohibited by law, a serious violation.

\section{Contingent Factors Affecting the Position of Public Relations}

The Contingency of Accomodation Theory emphasizes that the attitude or position of a PR is very dynamic and depends on changing situations. This change in situation is determined by variables. There are 86 variables and they are developed into new variables, namely predisposing variables and situational variables, each of which has 6 contigens (CA) (Cancel et all, 1999). All of the contingent factors in the predisposing and situational variables were taken into account by the attitudes and position of the TVOne company PR in overcoming hoax information problems, namely;

\section{Contingent Factors in Predisposing Variables}

a. Large organization size: The results of the interview show that tvOne is the number one tv news and sport in Indonesia, so that with this power tvOne has greater compressive power in the realm of law. If the hoax information problem has content that is considered to be very detrimental to the company, his party can immediately bring the problem to the realm of law.

b. Open organizational culture: tvOne is a company that has an open organizational culture type. This can be seen by the informants' admission of several hoax cases that occurred, tvOne quickly opened information to the public through clarification on tvOne's social media or providing direct statements on tvOne's news program. It also conducts press conferences and distributes press releases to the media.

c. Exposure or business disclosure is quite worrying: Stakeholders must be protected from being exposed to hoaxes are consumers, if consumers do not watch, then no one will see the advertisement broadcast on tvOne. According to informant two, if there is more hoax information that attacks tvOne and is not handled immediately, the media business disclosures will be disrupted. This can make pengilklan think many times about placing advertisements on tv which is known as tv hoax, which is very detrimental to tvOne.

d. Ease of access to Public Relations with dominant groups makes it easier to coordinate problem solving: According to the first informant, tvOne's PR manager, they have a routine weekly meeting agenda. The meeting aims to find out the state of various programs and divisions in tvOne, but if there is an emergency coordination can be done directly by phone contact. On the other hand, according to the fifth informant, there is a WhatsApp group to facilitate coordination and formulation of problem solving strategies, including hoax information problems. In the group there are leaders and across PR divisions with other divisions to facilitate coordination.

e. The strength of decisions and direction of dominant qualifications are priorities: PR tvOne and their ranks act according to the direction of the 
Editor in Chief and the management to take action against the hoax spreaders. Including the decision to act as advocacy or accommodation in preparing hoax cases that harm tvOne

f. TvOne CEOs are quite cooperative (Key individual characters): tvOne's PR has no difficulty communicating with the vice president director. But not all hoax information that attacks tvOne they coordinate with the editor in chief, except for hoax information that is large and viral. The three cases that were the object of this research according to the informants were formulated directly with the leaders including the deputy director of the tvOne company so that they could immediately take action and attitudes quickly.

\section{Contingent Factors in Predisposing Variables}

a. Threats such as negative reporting and legal issues have been passed: The three cases of hoax information that harm tvOne, according to the first informant, are very dangerous because they cause negative news to corner tvOne. Of the three hoax cases, two cases were brought to the realm of law because they were considered to be very detrimental to tvOne.

b. Potential costs can be minimized: The three hoask cases PR tvOne is in an advocacy position to reduce the cost of losses both material and non-material. On the other hand, the advocacy position is considered to reduce risks such as damage to public and stakeholder trust as well as advertisers about tvOne as a news tv that presents information based on facts, not false information.

c. The importance of maintaining a balance between various publics: Hoax information can disrupt the balance of public interests, because tvOne aims to educate viewers through information and news products that are in accordance with facts.

d. Public perception of the issue is quite dangerous: Hoax cases that are detrimental to tvOne, namely the three cases that were sampled in this study were quite viral and could have potential problems with negative perceptions from the public. According to the sources, if the dominance of public perception is negative due to hoax information, the public's trust in the information and news provided by tvOne will be damaged, thus endangering the company.

e. Organizational reputation can be compromised: Reputation is an inherent value; authenticity, honesty, responsibility and integrity arising from the personality of the company image (Suwanto, 2018). In the three cases of hoax information that attacked tvOne, according to informants, the reputation was considered quite disturbed and had a bad impact on the public's view of tv One as the big news tv in Indonesia.

f. The character of the external public is diverse and guides information based on facts: The external public that deserves to be guarded according to tvOne's PR is to prioritize tvOne's viewers, they want correct information not confusing hoax information. According to other informants, tvOne's news 
viewers are very diverse and the majority of sizes are C 2, D and E. If tvOne is considered to be spreading false or hoax information, then if allowed to tvOne the audience may decrease, because they want information based on facts.

\section{New Contingent Factors, "Image and Credibility"}

In the research process carried out by the researcher by taking semistructural interview data and documentation, the researcher found two new continuum, namely image and credibility. Of the five sources, all of them always mentioned that the variables of image and credibility or trsut were important things to maintain and should not be damaged due to hoax information that was detrimental to tvOne, in this case the three viral cases, namely 2016, 2018 and 2020.

According to Frank Jefkins, image is defined as the impression of a person or individual about something that appears as a result of their knowledge and experience. Another understanding of image was expressed by Katz, who said that image is the way other parties perceive a company, person, committee, or activity (Soemirat, 2010). Company image is a flexible and changing construct, influenced by the knowledge, attitudes, and behavior of the recipient towards an organization at a certain point (Williams \& Moffit, 1997). According to the informants, negative public comments will lead to negative perceptions of cases of hoax information that are detrimental to tvOne, this could endanger tvOne's well-built image.

Then related to the credibility content, the meaning of credibility is a multidimensional concept that includes trustworthiness, expertise and power (Soemirat and Elvinaro, 2010). According to the third informant, tvOne's credibility as tv news and sport must also be preserved as a holy object so that the audience can still watch tvOne. Credibility is very close to trust and trust is very important for a company to maintain, especially media companies. Because when trust falls, the public will no longer believe it, business circulation can go down and business can be disrupted.

Image contingent factors and credibility can be added to situational variables whose conditions of public perception differ every time depending on the situation and conditions. So that the PR tvOne and its staff must be able to maintain these two things well, because tvOne is a news tv whose main product is information that is in accordance with facts and data. According to the informants, if the information provided by tvOne is in doubt, this could be very dangerous for tvOne.

Table 3: Predisposing Variables and Situational Variables in Contingency of

Accommodation (CA) Theory

\begin{tabular}{|l|l|l|}
\hline No & \multicolumn{1}{|c|}{ Variable } & \multicolumn{1}{c|}{ Contingent Factors } \\
\hline 1. & Predisposing & 1) Organization Size \\
& Variables & 2) Organizational Culture \\
& & 3) Business exposure or exposure \\
& & 4) Affiliation or access to PR with the dominant group \\
& & 5) Strength of Decisions and Direction of Dominant \\
& & \multicolumn{2}{|c|}{ Qualifications } \\
\hline
\end{tabular}




\begin{tabular}{|l|l|l|}
\hline 2. & $\begin{array}{l}\text { 6) } \begin{array}{l}\text { Individual characteristics of key individuals, such } \\
\text { as the CEO. }\end{array} \\
\text { Variables }\end{array}$ & $\begin{array}{l}\text { 1) Threats such as negative news published in the } \\
\text { media, government intervention, legal issues } \\
\text { (litigation) } \\
\text { 2) Potential Costs or Benefits of a Strategy } \\
\text { (Accommodation or Advocacy) } \\
\text { 3) Balance of interests between various publics. } \\
\text { 4) Public perception of the issue } \\
\text { 5) Reputation of the organization } \\
\text { 6) The characteristics of the external public and their } \\
\text { demands }\end{array}$ \\
\cline { 2 - 4 } & Variables found \\
by Researchers & $\begin{array}{l}\text { 1) Image } \\
\text { 2) Credibility }\end{array}$ \\
\hline
\end{tabular}

Source: Cancel et all, 1999 processed by Researchers

\section{Domination of Advocacy Attitudes: Mainstream News Media Companies, Uphold the "truth" as a foundation for gaining public trust}

An interesting finding is the characteristic of mainstream media companies that maintain the value of truth, according to journalistic principles. TVOne media company is one of the big news tv companies in Indonesia, so that Public Relations and management immediately make various efforts to resolve hoax information problems that are detrimental to the company. According to the fourth informant, hoax information is false and misleading information. There is a most basic principle in the journalistic principle of information, namely the value of truth.

The truth is measured by how accurate the information is conveyed through multiple confirmations. That is what distinguishes between what is conveyed by the mainstream media and the information conveyed by social media. So that according to the fourth informant, hoaxes are not known in the principles of journalism. For the news media, hoaxes are very important to resolve, because they can damage the image and credibility of media companies as disseminators of information based on true facts.

Regarding facts and truth, McQuail $(2011,222)$ in his book entitled Mass Communication Theory, states that the most core concept of media theory related to information quality is objectivity, especially when it comes to news information. One version of the objectivity component is explained by Westerstahl that objective news presentation must include values and facts, the fact itself has evaluative implications. The dimension of objectivity consists of (1) factuality, and (2) impartiality. Factuality consists of: (a) truth, (b) informative, and (c) relevance. While impartiality consists of: (a) balance and (b) neutrality (McQuail, 2011).

Then according to another informant, hoaxes are information that does not match the breath of the news tv media business. Public trust in the credibility of the 
media can be disrupted due to negative things such as hoax information. So that the hoax problem must be resolved seriously, and PR tvOne must act to defend the company. Because the media is a company that sells products of public trust through the reporting of correct information.

\section{E. CONCLUSION}

The conclusions that can be drawn by researchers in research involving three cases of hoax information detrimental to tvOne in 2016 with nitizen anonymus, 2018 with the Instagram account @bola_gila and in 2020 with the online media Sintesa are as follows. The use of the Contogency of Accomodation theory is a complement to Excellent theory. This theory shows that the position of PR does not always accommodate the public, sometimes it is ethical for organizations to stand firmly in full support of the organization. Researchers use this theory to see the dynamics of the position of PR in overcoming hoax information and the results from the dynamics of PR positions and actions leading to an advocacy position. However, in the second case, there was a situation where PR tvOne made accommodations in advocacy, by forgiving the hoax spreader and withdrawing the lawsuit, but his party still blamed the hoax act so that it remained in the quantum position of advocacy.

Then on the contingent factors in the predisposing and situational variables, each of which has six continuum, it turns out that all affect tvOne's PR attitude in overcoming hoax information. However, in this study, the researcher found two new continuum which is very important for tvOne company as a news media company whose main product is "information" is "image and credibility". Image is to show how public perceptions and interpretations of a company can change at any time. Then credibility is more on the public's trust in the quality and ability of an object, in this case the tv news media company tvOne. Both of these can be added to situational variables, because public perceptions of image and credibility can change according to certain conditions.

In this research, it was revealed that the characteristics of the mainstream news media strongly emphasize the value of truth in the journalistic principles of news processing. So that with the hoax information, it is considered important problems that must be resolved immediately. According to informants, hoax information or fake news can create negative perceptions in the eyes of the public, thereby reducing the value of their trust in mainstream media companies including PT Lativi Media Karya (tvOne) which broadcasts various information that has news value and truth value in its news.

On the other hand, the limitation of this research is that the researcher looks for the dynamics of the position of PR in the strategy of overcoming hoax information using only one media company, namely the company PT Lativi Media Karya or tvOne as the news tv media. So that in further research, it can be developed with more other media companies in order to get good data comparisons to draw data conclusions. Then this research can also be developed in other non-profit- 
oriented or profit-oriented companies such as the mining, oil and gas, or investment sector companies that have special public characteristics.

Another limitation or limitation is that this research was conducted in Indonesia, so that in the future it can still be developed in other media companies in other countries in the Americas or Europe which have different public characteristics. So that this research can help other PR media to map the strategy and position of the PR attitude of media companies in dealing with hoax information that will increasingly increase in today's digital era.

\section{REFERENCES}

1. Aditiawarman, M. (2019). Hoaks dan hate speech di dunia maya. Padang: Lembaga Kajian Aset Budaya Indonesia Tonggak Tuo.

2. Akil. (2012). Ilmu Komunikasi: Konstruksi, Proses, dan Level Komunikasi Kontemporer. Makasar: Alauddin University Press.

3. Alemanno, A. (2018). Editorial: How to counter fake news? A taxonomy of antifake news approaches. European Journal of Risk Regulation, 9, 1-5.

4. Briantika, A. (2018). TvOne Laporkan akun @bola_gila soal kasus hoaks hasil piala dunia. Retrieved from: https://tirto.id/tvone-laporkan-akun-atbola-gilasoal-kasus-hoaks-hasil-piala-dunia-cNn6

5. Bungin, B. (2010). Penelitian Kualitatif. Jakarta: Kencana Prenada Media Grup.

6. Bungin, B. (2017). Politik Hiperreality dan Communicatioan Jammed. Dalam Buku Turn Back Hoaks Tantangan Literasi Media Digital. Surabaya: Buku Litera dan Aspikom Korwil Jawa Timur.

7. Cameron, G.T. (2008). Public Relations Today: Managing Competition and Conflict. Boston, MA: Pearson/Allyn and Bacon.

8. Cameron, G.T., Pang, A., \& Jin, Y. (2008). Contingency theory: Strategic management of conflict in public relations. In T.L. Hansen-Horn E B.D. Neff (Eds.), Public relations: From theory to practice (pp. 134- 157). New York: Pearson.

9. Cancel, A. E., Cameron, G. T., Sallot, L. M., \& Mitrook, M. A. (1997). It depends: A contingency theory of accommodation in public relations. Journal of Public Relations Research, 9(1), 31-63.

10. Cancel, E., Mitrook, A., \& Cameron, T. (1999). Testing the contingency theory of accommodation in public relations. Journal Public Relations Review, 25(2), 171-197.

11. Creswell, J. (2019). Research Design Pendekatan Metode Kualitatif, Kuantitatif, dan Campuran. Yogyakarta: Pustaka Pelajar.

12. Hartley, J. (2012). Digital Futures for Cultural and Media Studies. United Kingdom: John Wiley \& Sons.

13. Ikhsanudin, A. \& Wildansyah, S. (2019). Kasus Hoaks Skor Piala Dunia, tvOneAkun IG Bola Gila Berdamai. Retrieved from: https://news.detik.com/berita/d4428082/kasus-hoax-skor-piala-dunia-tvone-akun-ig-bola-gila-berdamai

14. Jin, A., Pang, A., \& Cameron, T. (2006). Strategic communication in crisis governance: Analysis of the Singapore Management of the SARS. The Copenhagen Journal of Asian Studies, 23, 81-104. 
15. Kriyantono, R. (2014). Teknik praktis riset komunikasi. Jakarta: Prenada Group.

16. Kriyantono, R. (2017). Teori-Teori Public Relations Perspektif Barat E Lokal: Aplikasi Penelitian dan Praktik. Jakarta: Kencana.

17. Lincoln, Y., \& Guba, E. (1985). Naturalistic inquiry. California: SAGE Publications, Inc.

18. McQuail, D. (2011). Teori Komunikasi Massa, Penerjemah Putri Iva Izzati. Jakarta: Salemba Humanika.

19. Pusparisa, Y. (2019). Puncak Penyebaran Hoaks Terjadi Menjelang Pilpres 2019. Retrieved from: https://databoks.katadata.co.id/datapublish/2020/01/07/jelangpemilu-hoaks-makin-berseliweran

20. Priliawito, E. (2020). TVOne: ILC tak mungkin gunakan narasumber palsu. Retrieved from: https://www.vivanews.com/berita/nasional/39156-tvone-ilc-tak-mungkingunakan-narasumber-palsu?medium=autonext

21. Pyrcek, A. (2020). How media organizations can get real and confront fake news. Retrieved from: https://www.ey.com/en gl/forensic-integrity-services/howmedia-organizations-can-get-real-and-confront-fake-news

22. Rimawan, R. (2016). Klarifikasi 'Meme Lebaran Diundur Tiga Tahun Lagi'. Retrieved from: https://www.tribunnews.com/metropolitan/2016/07/05/klarifikasi-memelebaran-diundur-tiga-tahun-lagi-tvone-mengaku-dizalimi

23. Soemitro, S \& Ardianto, E. (2010). Dasar-Dasar Public Relations. Bandung: Remaja Rosdakarya.

24. Strasburg, S., A. (2016). An Exploration of Contgency Theory of Accommodation: Communicating Environmental Sustainability Measure in Norway. Thesis. The Faculty of the Graduate School at the University of Missouri, US.

25. Suwatno. (2018). Pengantar Public Relations Kontemporer. Bandung: Remaja Rosdakarya.

26. Wahab, A., \& Rahim. S. (2013). Kredibiliti media dan penyertaan dalam persekitaran pengdemokrasian maklumat di Malaysia. Jurnal Komunikasi Malaysian Journal of Communication, 29(1), 141-160.

27. Williams, S. L., \& Moffitt, M. A. (1997). Corporate Image as an Impression Formation Process: Prioritizing Personal, Organizational, and Environmental Audience Factors. Journal of Public Relations Research, 9(4), 237-258

28. Yusuf. (2012). Kominfo Temukan 1.401 Sebaran Isu Hoaks terkait Covid-19. Retrieved from: https://aptika.kominfo.go.id/2020/05/kominfo-temukan-1-401-sebaran-isuhoaks-terkait-covid-19/ 